\title{
ASSESSMENT OF DEPRESSION AND ANXIETY DISORDERS IN PATIENTS IN PRIMARY HEALTH CARE
}

\author{
F. Chyczii ${ }^{1}$, J. Alexandre', A. L. Santos ${ }^{1}$, C. Ramos ${ }^{1}$, L. Jesus ${ }^{1}$ \\ ${ }^{1}$ ACeS Douro I - Marão e Douro Norte, USF Fénix, Vila Real, Portugal
}

\section{BACKGROUND}

Depression and Anxiety Disorders are highly prevalent in Portuguese population. The diagnosis and prevention of this disabling disorders, are an importante issue in Primary Health Care. The aim of this study was to describe the levels of anxiety, stress and depression in a sample of patients from a family health unit in the north of Portugal; and to analyse the differences between genders and their relationship with health status, age, professional status, literacy and psychiatric medication intake.

\section{MATERIALS AND METHODS}

Descriptive co-relational study using a Portuguese version of the Depression, Anxiety, and Stress Scale-short form (DASS-21), in a consecutive sample of 207,64 men and 142 women, mean age $54 \pm 18,64$ years old.

\section{RESULTS}

GRAPHIC 1 - PARTICIPANTS BY AGE

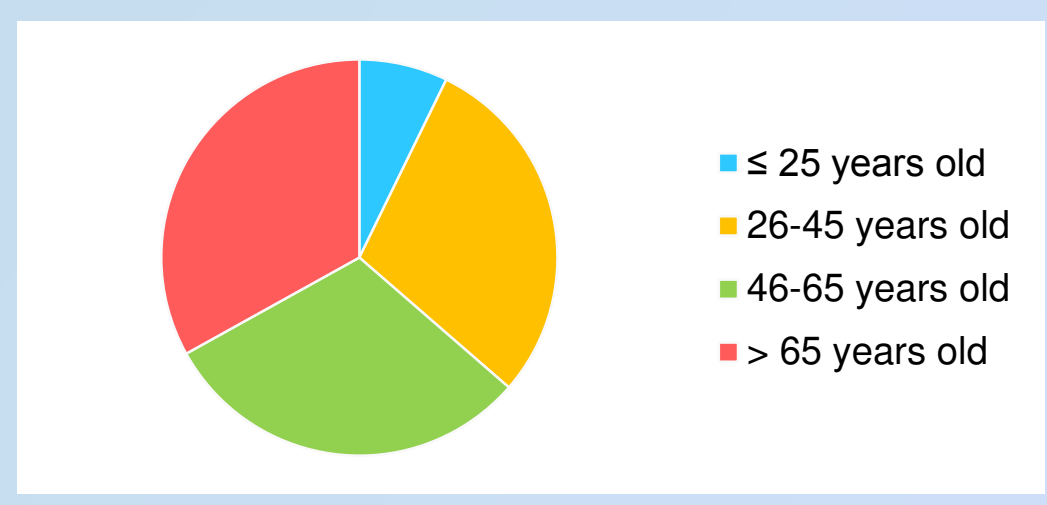

GRAPHIC 2 - SOCIO-DEMOGRAPHIC AND CLINICAL SAMPLE CHARACTERIZATION

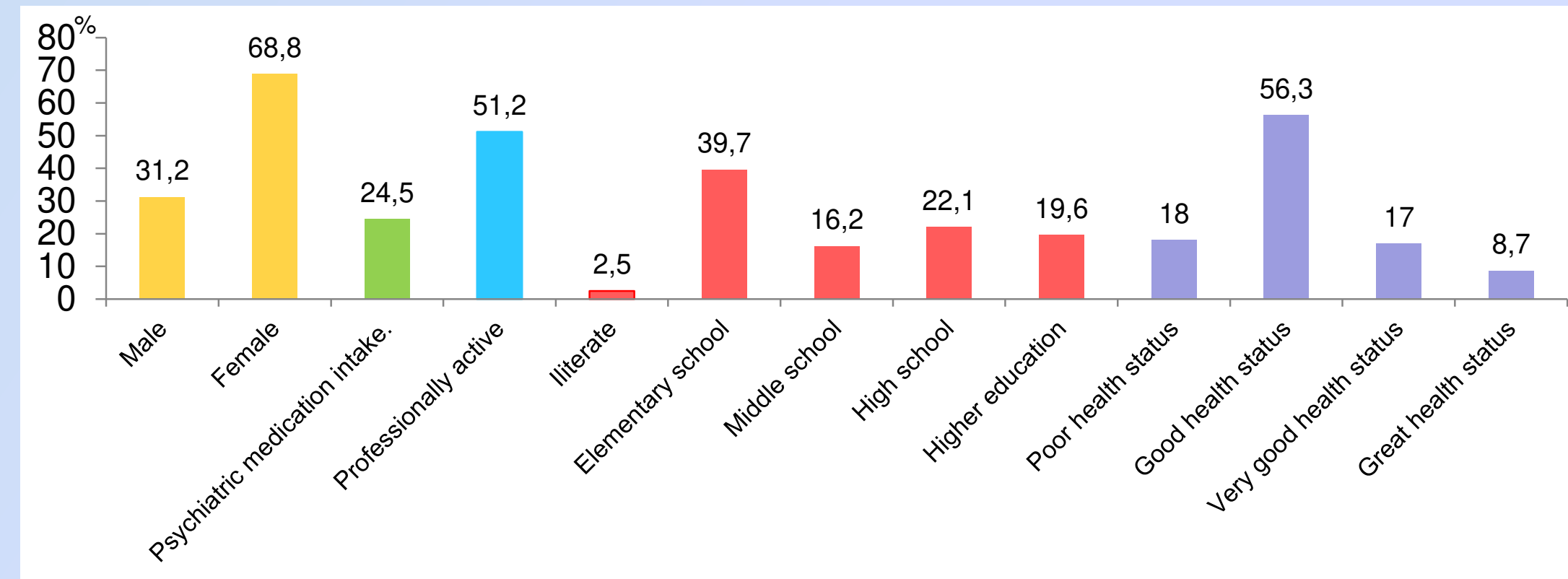

TABLE I - CORRELATION BETWEen VARIABLES

\begin{tabular}{|c|c|c|c|c|c|c|c|c|}
\hline \multirow{2}{*}{ Variables } & \multicolumn{2}{|c|}{ Stress } & \multicolumn{2}{|c|}{ Anxiety } & \multicolumn{2}{|c|}{ Depression } & \multicolumn{2}{|c|}{ Score 21} \\
\hline & $x^{2}$ & $\alpha$ & $x^{2}$ & $\alpha$ & $X^{2}$ & $a$ & $x^{2}$ & $\alpha$ \\
\hline $\begin{array}{l}\text { Psychiatric } \\
\text { medication }\end{array}$ & 2,816 & 0,093 & 9,263 & 0,026 & 7,429 & 0,024 & 9,493 & 0,023 \\
\hline Literacy & 1,217 & 0,875 & 16,031 & 0,190 & 14,089 & 0,079 & 19,974 & 0,068 \\
\hline Professional status & 0,144 & 0,930 & 6,130 & 0,409 & 1,841 & 0,765 & 9,323 & 0,156 \\
\hline Health status & 7,493 & 0,058 & 8,938 & 0,443 & 11,197 & 0,082 & 25,901 & 0,002 \\
\hline
\end{tabular}

TABLE II - CoRRELATION BETWEen DASS-21 SubSCALE SCORES IN THREE DIMENSIONS STRESS, ANXIETY AND DEPRESSION

\begin{tabular}{c|c|c|c|c|}
\hline & & DASS & DASS & DASS \\
\hline \multirow{2}{*}{ DASS } & $\mathrm{r}$ & 1 & Anxiety & Depression \\
\hline Stress & $\mathrm{p}$ & - & 0,790 & 0,792 \\
\hline \multirow{2}{*}{ DASS } & $\mathrm{N}$ & 198 & 193 & 0,000 \\
\hline Anxiety & $\mathrm{r}$ & 0,790 & 1 & 0,736 \\
\hline \multirow{2}{*}{ DASS } & $\mathrm{p}$ & 0,000 & - & 0,000 \\
\hline Depression & $\mathrm{N}$ & 193 & 200 & 185 \\
\hline & $\mathrm{r}$ & 0,792 & 0,736 & 1 \\
\hline & $\mathrm{p}$ & 0,000 & 0,000 & - \\
\hline
\end{tabular}

\section{DISCUSSION AND CONCLUSION}

Between $82,5 \%$ to $92,4 \%$ of individualls show normal levels of stress, anxiety and depression; $4,2 \%$ to $9 \%$ moderate and $3 \%$ severe. Women present higher mean levels of anxiety disorders. A strong association between depression, anxiety and psychiatric medication intake was observed. The short version of the Depression Anxiety Stress Scale - 21 can be reliably used to measure depression and anxiety disorders in patients in Primary Health Care. Our results showed lower levels of depression, anxiety and stress compared to other studies. The higher prevalence of anxious symptoms in women requires greater attention by health professionals. The gender difference and the strong correlation between the studied variables, demonstrated the importance of individual intervention strategies, particularly with regard to women and older individuals.

\section{REFERENCES}

Depression and Other Common Mental Disorders: Global Health Estimates. WHO 2017

Depressão e outras perturbaçoent

mentais-comuns-pdf.aspx.

(2008: Série 2 (8):45-9.

Apóstolo J, Figueiredo M, Mendes A, Rodrigues M. Depressão, ansiedade e estresse em usuários de cuidados primários de saúde. Rev. Latino-Am. Enfermagem. 2011; 19(2)::06 telas].

Direção-Geral da Saúde. Programa Nacional para a Saúde Mental. Lisboa: 2017. Acedido a 02/03/2019 através de: https://www.dgs.pt/portal-da-estatistica-da-saude/diretorio-de-informacao/diretorio-de-informacao/por-serie-883589-pdf.aspx?v=11736b14-73e6-4b34-a8e8d22502108547

Lovibond PF, Lovibond SH. The structure of negativ emotional states: comparison of the Depression Anxiety Stress Scales (DASS) with the beck depression and anxiety inventories. Behaviour Research and Therapy. 1995; 33(3): 335-343.

Apóstolo JLA, Mendes AC, Azeredo ZA. Adaptação 